\title{
DEVELOPMENT AND CHARACTERIZATION OF POLYCLONAL ANTIBODY OF RECOMBINANT HUMAN INTERFERON A2B IN NEW ZEALAND WHITE RABBIT
}

\author{
Heny Rachmawati*, L. Agustina R.A. Ningrum, D.S. Retnoningrum
}

\begin{abstract}
Lab. of Pharmaceutical Biotechnology, School of Pharmacy Institut Teknologi Bandung Jl. Ganesha 10 Bandung West Java, Indonesia
\end{abstract}

Submitted: 01-03-2014 Revised: 03-03-2014 Accepted: 15-04-2014

*Corresponding author Heny Rachmawati

Email :

h_rachmawati@fa.itb.ac.id

\begin{abstract}
We have developed recombinant wild type and mutant human interferon $a 2 b$ (rhIFNa2b) from synthetic gene in Escherichia coli. To identify the successful product of the proteins, immunology-based assay was suggested due to specificity for characterization. This work was aimed to develop and characterize rhIFNa2b polyclonal antibody generated in White New Zealand rabbits. The rhIFNa2b was overproduced in Escherichia coli BL21 containing rhIFNa2b synthetic gene in pET32b.The protein was obtained as inclusion bodies, refolded, purified using nickel affinity chromatography, and characterized using polyacrylamide gel electrophoresis. The purified rhIFNa2b protein was injected into rabbits for 21 days. Absorption of E.coli antibody was done using total $E$. coli protein to remove antibody againts host cell. The generation of antibody was monitored using dot blot and Western blot methods and quantified using Enzyme Linked Immunsorbant Assay (ELISA). To do so, rhIFN $\alpha 2 b$ was used as an antigen. The result showed that the rhIFNa2b was produced as a His-tag protein fusion of $33 \mathrm{kDa}$ in size. The results of dot blot and Western blot analyses strongly indicated that antibody against rhIFNa2b was generated and specifically recognized rhIFNa2b. ELISA showed that the titer of the polyclonal anti-rhIFNa2b was 1:10.000. In conclusion, polyclonal antibody spesifically against rhIFNa2b protein was successfully detected with high titer after 21 days after rabbit immunization.
\end{abstract}

Key words: polyclonal antibody, rhIFNa2b, New Zealand White rabbits.

\section{INTRODUCTION}

Interferon (IFN) is an endogenous cytokine generated as a response to virus, parasites, and mitogen. Based on its receptor, IFN is classified into type I (primary secreted by leukocytes and fibroblast) and type II (mainly produced by T-cells). IFN type I consists of IFN $\alpha, \operatorname{IFN} \beta, \operatorname{IFN} \varkappa$, and IFN $\tau$, while type II consists of IFN $\gamma$ [Baldarrain et al.s, 2001]. Currently, IFN has been developed for antiviral and anticancer treatments. However, the therapeutic use of IFN limited clinical application due to its short biological half life, its protease instability, and other side effects Jonasch and Halusca, 2001; Thitinan and McConville, 2009).

IFN $\alpha 2 b$ is the mostly studied of IFN type I. It has been approved by World Health Organization for therapeutic use against hepatitis $B$ and $C$ virus infections. In our previous research, recombinant human IFN $\alpha 2 b$ (rhIFN $\alpha 2 b)$ coding region was synthesized using Thermodynamically Balanced Inside-Out method. An Escherichia coli BL21 carrying pET32b inserted by the rhIFN $\alpha 2 b$ coding region was used to produce rhIFN $\alpha 2 b$. The rhIFN $\alpha 2 b$ was successfully purified and characterized (Retnoningrum et.al., 2010).

Polyclonal antibody has been widely used in immunoassay, especially in research and clinical laboratories. Polyclonal antibody has wide application such as immunoblotting and immunostaining to identify and characterize antigens. It is also used for characterization of engineered protein and immunoprecipitation. Polyclonal antibody is commonly generated from immunized animals:rabbit, rat, mice, and horse. In the laboratory scale, rabbit is generally used because of its size, its easiness in handling, 
and its ability to generate higher amount of antibody as compared to rat or mouse (Asai, 1993).

We reported here the successful development of antibody anti-rhifn $\alpha 2 b$ in White New Zealand rabbit. Our established rhifn $\alpha 2 \mathrm{~b}$ was used as an antibody inducer as well as to detect the antibody generation both qualitatively and quantitatively.

\section{MATERIAL AND METHODS Microorganism animal and growth medium}

Escherichia coli harboring pET32b IFN $\alpha 2 b$ (E. Coli pET32b IFN $\alpha 2 b$ ) was constructed in our previous work and was used as a source to obtain rhIFN $\alpha 2 \mathrm{~b}$ protein. Rabbit strain White New Zealand (12 weeks, $2 \mathrm{~kg}$, female and male) was obtained from PT Bio Farma (Persero, Bandung, Indonesia). Luria Bertani agar and broth containing $100 \mu \mathrm{g} / \mathrm{mL}$ ampicillin was used to growth recombinant E. coli.

\section{Protein overproduction, purification and characterization.}

E. coli $\mathrm{pET} 32 \mathrm{~b}$ IFN $\alpha 2 \mathrm{~b}$ was inoculated in $30 \mathrm{~mL}$ of Luria Bertani (LB) liquid medium containing $100 \mu \mathrm{g} / \mathrm{mL}$ ampicillin (Sigma, New York, USA). The growth of the bacteria was done at $37^{\circ} \mathrm{C}, 150$ rotation per minutes (rpm) for $16 \mathrm{~h}$ with rigorous shaking. $5 \%(\mathrm{v} / \mathrm{v})$ of $16-$ hour inoculum was added into $320 \mathrm{~mL}$ of $\mathrm{LB}$ broth containing $100 \mu \mathrm{g} / \mathrm{mL}$ ampicillin for 3 hours. Culture was induced at OD600 $\sim 0.5$ using $0.5 \mathrm{mM}$ isopropyl $\beta$-D-1-thiogalactopyranoside (IPTG, Sigma) and culture was incubated for additional 3 hours in the same condition. Cells were collected by centrifugation at $1.300 \mathrm{x} \mathrm{g}$ for $15 \mathrm{~min}$. The pellet was washed in $6 \mathrm{~mL}$ of binding buffer without imidazole containing $1 \mathrm{mM}$ of phenyl-methylsulphonyl fluoride (PMSF, Sigma). The cells were disrupted by sonication at $4 \mathrm{MHz}$ for $10 \mathrm{~min}$. Cells were sonicated for $30 \mathrm{~s}$ and then allowed to cool down for another 30s on ice. Suspension was centrifuged at 5.000x $\mathrm{g}$ for $15 \mathrm{~min}$. Most of the rhIFN $\alpha 2 \mathrm{~b}$ protein was produced as inclusion bodies (IB) and refolded in $6 \mathrm{M}$ urea for $60 \mathrm{~min}$. Soluble rhIFN $\alpha 2 \mathrm{~b}$ was obtained by centrifugation at 5.000x $\mathrm{g}$ for $30 \mathrm{~min}$.
Nickel affinity chromatography was used to purify rhIFN $\alpha 2 \mathrm{~b}$ according to manufacturer (Novagene). $5 \mathrm{~mL}$ of total protein of $256 \mu \mathrm{g} / \mathrm{mL}$ was loaded and eluted protein was collected in 6 fractions. Purified rhIFN $\alpha 2 b$ protein was measured using Bradford method. Total and purified proteins were characterized by $15 \%$ Sodium Dudocyl Sulphate Polyacrylamide Gel Eelectrophoresis (SDS-PAGE). $20 \mu \mathrm{L}$ of sampel protein from 6 fraction of purified protein $(5.12 \mu \mathrm{g} ; 5.64 \mu \mathrm{g} ; 6.1 \mu \mathrm{g} ; 3.40 \mu \mathrm{g} ; 1.68 \mu \mathrm{g})$ were mixed with $5 \mu \mathrm{L}$ of sample buffer. Electrophoresis was done at $125 \mathrm{~V}$ for $60 \mathrm{~min}$.

\section{Generation of polyclonal antibody in rabbit.}

Purified $\mathrm{rhIFN} \alpha 2 \mathrm{~b}$ was sterilized with 0.22 micron filter.Concentration of protein was measured with Bradford method. The sterilized rhIFN $\alpha 2 b$ was used to immunize 2 different rabbits $(2.5 \mathrm{~kg}, 3$ months, and specific pathogen free) subcutaneously at five spots on the back site of the animals. The first immunization was conducted using1 $\mathrm{mL}$ of solution I containing $100 \mu \mathrm{g}$ purified rhIFN $\alpha 2 \mathrm{~b}$ protein in $0.5 \mathrm{~mL}$ of elute buffer and $0.5 \mathrm{~mL}$ complete Freud adjuvant. Reimmunization was done three times with $1 \mathrm{~mL}$ of solution II containing $200 \mu \mathrm{g}$ purified $\mathrm{rhIFN} \alpha 2 \mathrm{~b}$ protein in $0.5 \mathrm{~mL}$ of elute buffer and $0.5 \mathrm{~mL}$ incomplete Freud adjuvant in 14 days interval. Blood was collected 10days after each immunization and then incubated at $37^{\circ} \mathrm{C}$ for an hour. Serum was obtained after centrifugation at $900 \mathrm{xg}$ for $10 \mathrm{~min}$ and then was stored at $-20^{\circ} \mathrm{C}$ until used.

\section{Adsorption experiment.}

This step was aimed to adsorp antibodies againts E. coli BL21 total proteins in rabbit serum after immunization. Protein totals of $E$. coli was obtained from E. coli BL21 grown in $50 \mathrm{~mL}$ of LB broth. Cell pellet was disrupted with sonication and total proteins were separated by centrifugation at $124 \mathrm{x} g$ for $15 \mathrm{~min}$. Rabbit serum was mixed with total protein $(256 \mu \mathrm{g} / \mathrm{mL})$ at $7(\mathrm{v} / \mathrm{v})$ ratios, 1: 1.50; 1: $1.75 ; 1: 2.00 ; 1: 2.25 ; 1: 2.50 ; 1: 2.75$; and 1 : 3.00. The mixtures were incubated at room temperature for $30 \mathrm{~min}$ and centrifuged at $966 \mathrm{x}$ $\mathrm{g}$ for $2 \mathrm{~min}$. Supernatants were collected and stored at $-20^{\circ} \mathrm{C}$. 
Development and Characterization of Polyclonal

Characterization of polyclonal antibody.

Dot blot, Western blot and ELISA were used to characterize the antibody. In dot blot method, $1.2 \mu \mathrm{g}$ of purified $\mathrm{rhIFN} \alpha 2 \mathrm{~b}$ protein was blotted onto nitrocellulose membrane. Alkaline phosphatase-conjugated rat anti-rabbit IgG and elute buffer were used as positive and negative controls, respectively. Blocking of unspecific proteins was done by incubating nitrocellulose membrane in Phospate Buffer Saline (PBS) containing 5\% (w/v) of skim milk at room temperature for $60 \mathrm{~min}$ with gentle shaking. The membrane was then washed 3 times with TBST $[0.1 \%(\mathrm{v} / \mathrm{v})$ of Tween in Tris Buffer Saline (TBS)] then incubated with rabbit serum (dilution 1:2,500 using PBS containing $5 \%$ skim milk and $0.1 \%$ tween) at $4^{\circ} \mathrm{C}$ for two hours. The washing step was repeated 3 times with the same condition. The membrane was incubated with alkaline phospatase-conjugated rat anti-rabbit $\operatorname{IgG}$ (dilution 1:10,000 in TBS containing 5\% skim milk and $0.1 \%$ tween) at room temperature for an hour and then washed. The staining was developed by incubation in $33 \mu \mathrm{L}$ of Nitro Blue Tetrazolium Chloride (NBT, Sigma, $50 \mathrm{mg} / \mathrm{mL}$ )] and $66 \mu \mathrm{L}$ of 5-Bromo-4-chloro-3-indolyl phosphate (BCIP, Sigma, $50 \mathrm{mg} / \mathrm{mL}$ ) in $10 \mathrm{~mL}$ alkaline phospatase solution $(100 \mathrm{mM}$ sodium chloride; $5 \mathrm{mM} \mathrm{MgCl} ; 100 \mathrm{~mL}$ tris $\mathrm{HCl}, \mathrm{pH} 9.5)$ at dark room for $15 \mathrm{~min}$. Reaction was stopped by soaking membrane in $20 \mathrm{mM}$ EDTA solution.

\section{Western blot.}

The gel containing protein $(5.12 \mu \mathrm{g}$ and $5.64 \mu \mathrm{g})$ was transblotted onto nitrocellulose membrane in $1 \mathrm{~L}$ transfer buffer [2.2g glycine; $5.8 \mathrm{~g}$ tris base; $0.37 \mathrm{~g}$ SDS; $200 \mathrm{~mL}$ methanol (v/v); add aquadest up to $1 \mathrm{~L}, \mathrm{pH} 7,4]$ at 90 Volt for $90 \mathrm{~min}$. Nitrocellulose membrane was treated with the same procedure for dot blot.

\section{ELISA.}

$0.5 \mathrm{ng} / \mathrm{uL}$ of purified $\mathrm{rhIFN} \alpha 2 \mathrm{~b}$ in PBS was loaded into microtiter plate. The plate was incubated at $4^{\circ} \mathrm{C}$ overnight and washed with $200 \mu \mathrm{L}$ of PBST twice and $200 \mu \mathrm{L}$ of TBS once for each well. Blocking of unspecific binding was done with $5 \%$ of skim milk in PBS at room temperature for $60 \mathrm{~min}$. The plate was washed, incubated with rabbit's serum (dilution 1:1000-1:10.000) for an hour and washed again.
Plate was incubated with $200 \mu \mathrm{L}$ alkaline phosphatase-conjugate rat anti-rabbit $\operatorname{IgG}$ (dilution 1:5000 in PBS) at $37^{\circ} \mathrm{C}$ for $60 \mathrm{~min}$ and washed. The yellow color were developed by adding $200 \mu \mathrm{L}$ of PNPP $(1 \mathrm{mg} / \mathrm{mL}$ in $10 \%$ dietanolamin) into each well. The plate was incubated at $37^{\circ} \mathrm{C}$ for an hour. The adsorption was read by ELISA-reader (BioRad) at 405nm.

\section{RESULT AND DISCUSSION \\ Recombinant human IFNa2b over- production and purification.}

The amount of protein (total protein of E. coli, rhIFN $\alpha 2 \mathrm{~b} I B$, and purified rhIFN $\alpha 2 \mathrm{~b}$ ) (Table I). The result of SDS-PAGE methods for $E$. coli $\mathrm{pET} 32 \mathrm{~b}$ IFN $\alpha 2 \mathrm{~b}$ total soluble proteins from induced condition (Figure 1). Thick bands of $33 \mathrm{kDa}$ (theoretical size of protein fusion of $\mathrm{rhIFN} \alpha 2 \mathrm{~b}$ ) were observed which are indicating the correct protein.

Table I. Total Protein and Product yield

\begin{tabular}{lrcr}
\hline Fraction & $\begin{array}{c}\text { Volume } \\
(\mathbf{m L})\end{array}$ & $\begin{array}{c}\text { Total } \\
\text { protein } \\
(\boldsymbol{\mu g})\end{array}$ & $\begin{array}{c}\text { Product } \\
\text { Yield(\%) }\end{array}$ \\
\hline E.coli & 320 & 3.073 & 100 \\
pET32b & & & \\
IFN 2 2b's & & & \\
total protein & & & \\
IB & 12 & 1.686 & 55 \\
Purified IB & 6 & 1.060 & 34 \\
\hline
\end{tabular}

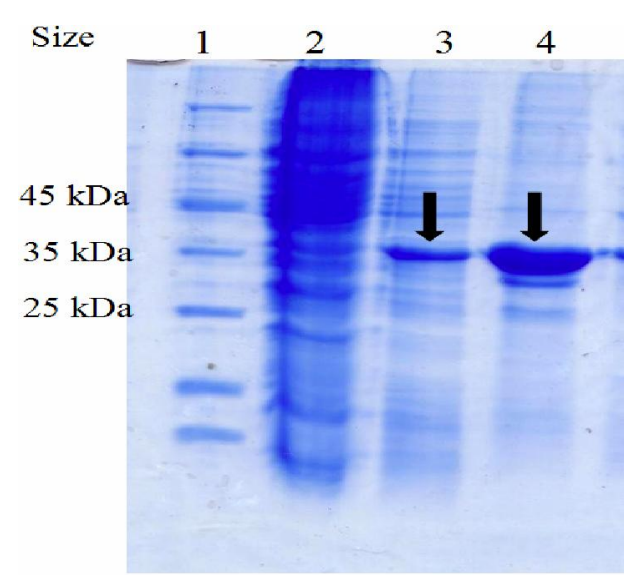

Figure 1. Coomassie briliant blue-stained 15\% SDS-PAGE of protein overproduction and purification. 1 = protein marker, $2=E$. coli total soluble proteins from induced condition, 3 $=$ refolded protein, $4=$ purified $\operatorname{rhIFN} \alpha 2 \mathrm{~b}$ from total refolded protein. 


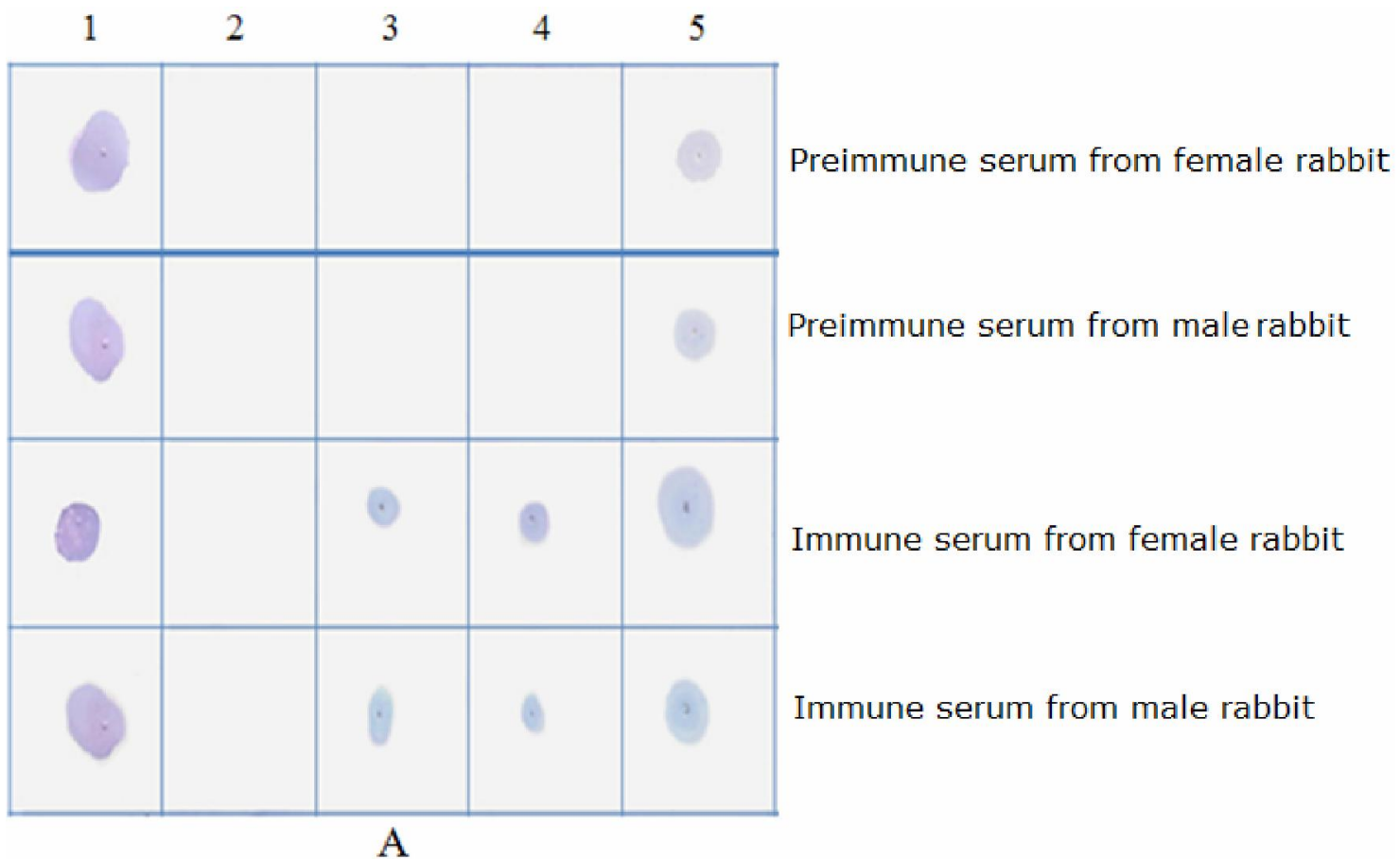

Figure 2. Dot blot of preimmune, immune and adsorbed rabbit sera. (A) Preimmune and immune sera. 1 = rat anti-rabbit $\operatorname{IgG}$ alkaline phosphate (positive control), 2 = elute buffer (negative control), $3=1.2 \mathrm{ng}$ of purifiedrhIFN $\alpha 2 \mathrm{~b}, 4=0.645 \mathrm{ng}$ of purifiedrhIFN $\alpha 2 \mathrm{~b}, 5=E$.coli BL21 total protein. (B) Serum from female rabbit, (C) serum from male rabbit . $1=1.28 \mu$ gof purified rhIFN $\alpha 2 \mathrm{~b}$ and E. coli BL21 total protein, $2=1.2 \mu \mathrm{g}$ purified rhIFN $\alpha 2 \mathrm{~b}$ (positive control), $3=$ elute buffer (negative control), 4 =ratio volume of rabbit sera to E. Coli BL21 total protein.

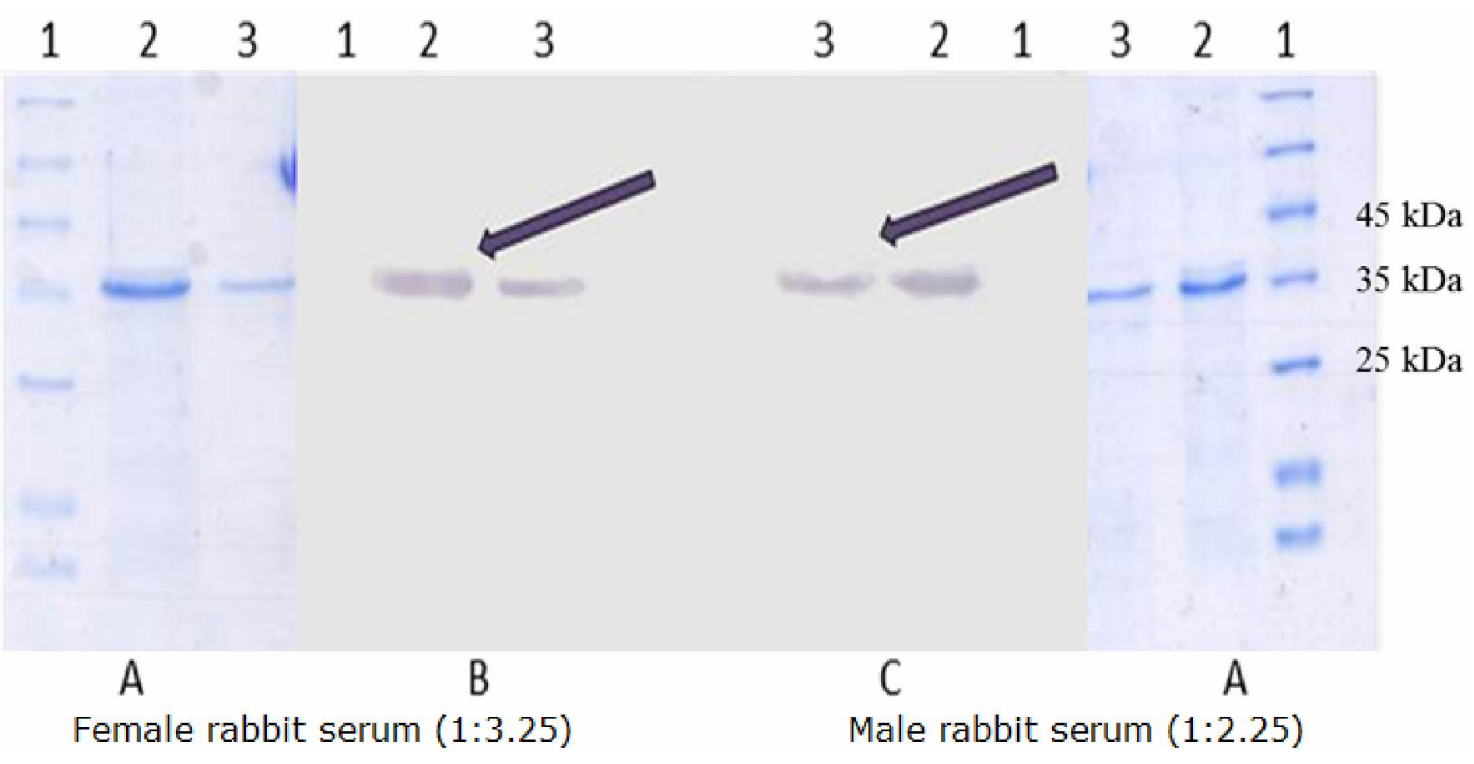

Figure 3. Characterization of rabbit sera by Western blot analysis using purified rhIFN $\alpha 2 \mathrm{~b} .15 \%$ SDS-PAGE (A),Western blots of sera from female (B) and male (C) rabbits. 1 = marker protein, 2 $=4.2 \mu \mathrm{g}$ of purified rhIFN $\alpha 2 \mathrm{~b}$ from IB, $3=3.4 \mu \mathrm{g}$ of purified rhIFN $\alpha 2 \mathrm{~b}$ from supernatant. 
Development and Characterization of Polyclonal

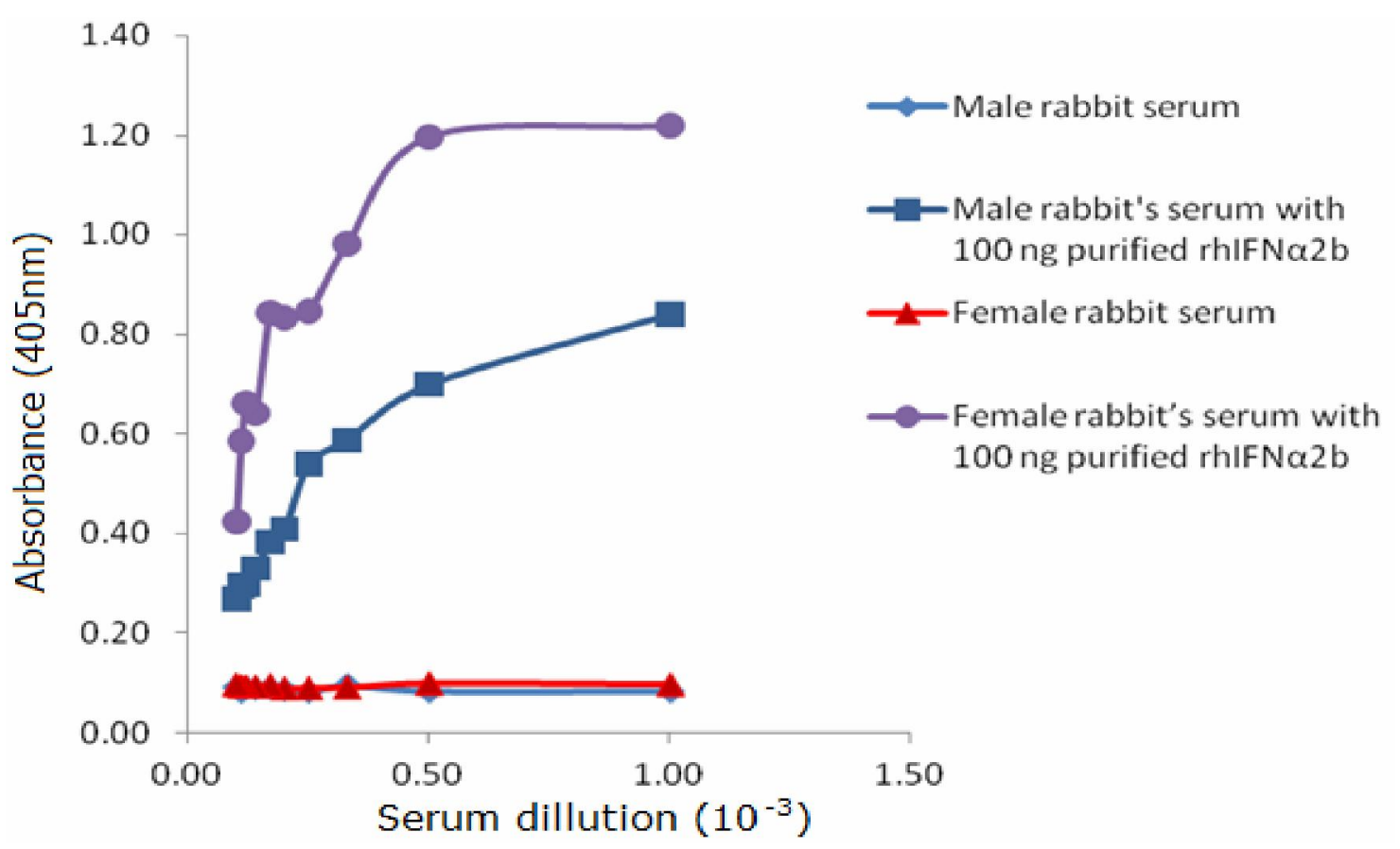

Figure 4.Titer assay of adsorbed polyclonal antibody against rhIFN $\alpha 2 \mathrm{~b}$ using ELISA.( $\mathbf{\Delta}$ ) female rabbit serum without rhIFN $\alpha 2 \mathrm{~b},(\checkmark)$ male rabbit serum without rhIFN $\alpha 2 \mathrm{~b}$, ( $\mathbf{(})$ male rabbit serum with 100 ngpurifiedrhIFN $\alpha 2 \mathrm{~b} ;(\bullet)$ female rabbit's serum with 100 ng purified rhIFN $\alpha 2 \mathrm{~b}$.

The rhIFN $\alpha 2 \mathrm{~b}$ protein which is expressed in E. coli mostly will form inclusion bodies (IB) and only a little was obtained from cytoplasm [Srivastava et al., 2005]. rhIFN $\alpha 2 b$ protein as IB can be refolded by $6 \mathrm{M}$ urea [Tsumoto, Ejima, and Kumagai, 2003]. rhIFN $\alpha 2 b$ protein from cytoplasm did not used because the concentration was too low.

\section{Production of polyclonal anti- recombinant human IFNa2b.}

Dot blot result from serum before immunization and after 10 days of the first immunization are shown in figure 2. No positive colour was produced from serum taken before immunization, indicating no antibody produced yet.In contrast, serum taken after 10 days of the first immunization showed positive result for both female and male rabbit's sera. In order to remove the antibodies against E.coli, the adsorption of anti-total protein was done at various concentrations. Theoptimum adsorption from female rabbit's serum was 1:3.00, while the male rabbit's serum was 1:2.25 (no colour produced at those ratios). Dot blot results from adsorption anti-total protein of E.coli BL21 are shown in figure 2 .

\section{Polyclonal anti-recombinant human IFNa2b characterization.}

The antibody produced was analyzed semi quantitatively with Western blot which is a specific method. Western blot analyses are shown in figure 3 . Purified $\mathrm{rhIFN} \alpha 2 \mathrm{~b}$ were run at 15\% SDS-PAGE. These membranes (Figure $3 . \mathrm{B}$ and $\mathrm{C}$ ) show thick and single purple bands at $33 \mathrm{kDa}$. The result of molecular weight by SDS PAGE was shown as a $33 \mathrm{kDa}$ band. Theoritically, the size of human IFN $\alpha 2 b$ protein is $19 \mathrm{kDa}$. From our previous research, rhIFN $\alpha 2 b$ protein was generated as fusion protein with $33 \mathrm{kDa}$ in size. This additional size was originated from $\mathrm{pET} 32 \mathrm{~b}$ expression vector (Retnoningrum, et. al., 2010). The purpose of constructing the fusion protein containing six histidine amino acid was for purification using nickel affinity chromatography.

The proteins were transferred to nitrocellulose membrane. The nitrocellulose membranes, figure 3 , show bands at $33 \mathrm{kDa}$ 
confirming the presence of anti-rhIFN $\alpha 2 b$ in rabbit's serum. The result from Western blot showed that anti-rhIFN $\alpha 2 b$ recognized rhIFN $\alpha 2 b$. A single band at $33 \mathrm{kDa}$, means that adsorption of anti-total protein of E. coli was optimum.

ELISA was used to determine antibody titer in female and male rabbit's serum. To find out the influence of serum dilution, a serial dilution of serum was made (1:1000-1:10.000) without addition of rhIFN $\alpha 2 \mathrm{~b}$. The result from this can be seen at Figure 4 and showed that the serum dilution did not have any influence in ELISA. The titer of both female and male rabbit's serum was 1:10.000. Absorbance from female rabbit's serum was higher than male. Generally, female mammalian generates higher antibody than male. This caused by esterogen hormone in female that increases inflammation response and antigen presenting process to $T$ and B cells [Bilbo and Nelson, 2001]. The findings we reported here is meaningful in the area of analytical method in particular for detection of rhifn $\alpha 2 \mathrm{~b}$. This protein is routinely produced in our laboratory for many purposes such as to study the pharmacokinetic profile, activity study in various model of immunerelated diseases. As rhifn $\alpha 2 b$ is a potent therapeutic protein for many chronic diseases, the successful production of this macromolecules confirmed by immunology based-analysis such as Western blot and ELISA opens way to explore more about potential function of rhifn $\alpha 2 \mathrm{~b}$ as a drug.

\section{ACKNOWLEDGEMENT}

The authors wish to thank School of Pharmacy ITB, for supporting research work.

\section{CONCLUSION}

rhIFN $\alpha 2 \mathrm{~b}$ protein was successfully overproduced from E. coli $\mathrm{pET} 32 \mathrm{~b}$ IFN $\alpha 2 \mathrm{~b}$. The protein was refolded and purified with nickel affinity chromatography. Purified rhIFN $\alpha 2 \mathrm{~b}$ protein was used to generate rhIFN $\alpha 2 b$ polyclonal antibody in New Zealand white rabbits. Polyclonal antibody was successfully generated confirmed with dot blot analysis.This antibody recognized protein at 33 $\mathrm{kD}$, i.e the size of rhIFN $\alpha 2 \mathrm{~b}$. Using protocol we developed, antibody was generated with high titer of 1:10,000 measured with ELISA.

\section{REFERENCES}

Asai, D.J. 1993. Antibodies in cell Biology. Academic Press. 16-50.

Bilbo, S.C. and R. J. Nelson. 2001. Sex Steroid Hormones Enhance Immune System in Male and Female Siberian Hamster. Am. J. Physiol. Regul. Integr.207-213.

Baldarrain, A., Y., Cruz, O., Navarro, and Gil, M. 2001. Purification and conformational properties of a human interferon $\alpha 2 \mathrm{~b}$ produced in Escherichia coli. Biotechnol. Appl. Biochem. 173-182.

Jonasch, E., F.G. Haluska. 2001. Interferon in Oncological Practice: Review of Interferon Biology, Clinical Applications, and Toxicities, Oncology, 6: 34-55.

Retnoningrum, D.S, Ningrum, R.A., Kurniawan, Y.N., Indrayati, A. and Rachmawati, H. 2010. Construction of synthetic open reading frame encoding human interferon alpha $2 \mathrm{~b}$ for high expression in E.coli and characterization of its gene product, J Biotech. 145, 193 198.

Srivastava, P., P. Battacharaya, G. Pandey, and K.J. Mukherjee. 2005, Overexpression and purification of recombinant Human Interferon Alpha $2 \mathrm{~b}$ in Escherichia col.Protein Expr. Purif. 41: 313-322.

Thitinan, S., and J. McConville. 2009. Interferon Alpha Delivery System for The Treatment for Hepatitis C, Int. J. Pharm. 369: 121-135.

Tsumoto, K., D. Ejima, and I. Kumagai. 2003. Practical consideration in refolding protein from inclusion bodies. Protein Expr. Purif. 1-8. 